\title{
Strategi Pembelajaran Materi PAI dengan Metode Hypnoteaching untuk Siswa Sekolah Dasar
}

\author{
Yusmicha Ulya Afif \\ IAIN PONOROGO \\ yusmicha@iainponorogo.ac.id
}

\begin{abstract}
Abstrak
Penelitian ini bertujuan untuk mendeskripsikan strategi pembelajaran materi PAI dengan metode hypnoteaching untuk siswa SD. Pusat Kurikulum Depdiknas mengemukakan bahwa, tujuan dari pendidikan agama Islam di Indonesia yaitu untuk menumbuhkan dan meningkatkan keimanan peserta didik melalui pemberian dan pemupukan pengetahuan, penghayatan, serta pengalaman peserta didik tentang agama Islam sehingga menjadi manusia muslim yang terus berkembang dalam hal berakhlak mulia, ketakwaan, dan keimanan dalam berbagai sendi kehidupan. Tercapainya tujuan pendidikan Agama Islam tentu tidak dapat lepas dari pemilihan strategi dan metode pembelajaran yang tepat guna. Dalam pembelajaran agama Islam materi-materi pendidikan tidak hanya untuk dipahami dan dihayati akan tetapi juga diamalkan dalam kehidupan sehari-hari. Melalui metode hypnoteaching, proses pembelajaran yang menggunakan pikiran bawah sadar ternyata memiliki kemampuan 10.000 kali lebih cepat daripada pikiran sadar, sehingga diharapkan bahwa dengan adanya sugesti-sugesti yang diberikan oleh guru dapat membantu meningkatkan kualitas hasil belajar serta pengamalan nilai-nilai pelajaran dalam kehidupan sehari-hari. Penelitian ini menggunakan pendekatan kualitatif dengan jenis penelitian pustaka. Pengumpulan data dilakukan dengan cara menelaah dari berbagai sumber pustaka yang relevan dengan penelitian kemudian disajikan dengan cara baru dan atau keperluan baru. Hasil dari penelitian ini adalah dengan metode hypnoteaching, anak-anak memiliki perubahan pada aspek akhlak sesuai dengan apa yang disampaikan, anak-anak lebih mudah untuk diajak kerjasama dalam proses pembelajaran, dan anak-anak lebih memiliki motivasi dalam belajar.
\end{abstract}

Kata kunci: Strategi pembelajaran, materi PAI, hypnoteaching

\begin{abstract}
This study aims to describe the PAI material learning strategy with the hypnoteaching method for elementary students. The Curriculum Center of the Ministry of National Education stated that the purpose of Islamic religious education in Indonesia is to grow and increase the faith of students through the provision and fertilization of knowledge, appreciation, and experience of students about the religion of Islam so that they become Muslim human beings who continue to develop in terms of noble character, piety, and faith in various aspects of life. The achievement of the goals of Islamic education certainly cannot be separated from the selection of appropriate learning strategies and methods. In Islamic religious learning educational materials are not only to be understood and lived but also practiced in everyday life. Through the hypnoteaching method, the learning process that uses the subconscious mind turns out to have the ability 10,000 times faster than the conscious mind, so it is hoped that the suggestions given by the teacher can help improve the quality of learning outcomes and practice the values of lessons in everyday life. day. This study uses a qualitative approach with the type of library research. Data collection is done by reviewing various library sources relevant to the research and then presenting it in a new way and/or new needs. The results of this study are the hypnoteaching method, children have changes in the moral aspect according to what is
\end{abstract}


conveyed, children are easier to cooperate in the learning process, and children are more motivated in learning.

Keywords: learning strategy, PAI material, hypnoteaching

\section{A. PENDAHULUAN}

Dalam pendidikan Islam, masa kanak-kanak adalah masa paling penting dalam menumbuhkembangkan segala potensi yang dimiliki oleh anak. Pada masa ini kita dapat memberikan stimulus-stimulus positif, karena yang meraka pelajari pada usia ini akan berpengaruh pada perkembangan mereka. Pada umumnya seorang anak akan belajar dari apa yang dilihat dan didengarnya. Sehingga sebagai orang tua, guru dan sebagai masyarakat pembelajar harus senantiasa memberikan contoh dan ajaran yang baik, sehingga disini anak dapat berkembang secara maksimal. Menurut pendapat Ibn al-Jauzi misalnya, dalam kitab alTib al-Ruhani yangk dikutip oleh Moh. Athiyah al-Abrasyi menyatakan bahwa, "Pembentukan yang utama ialah di waktu kecil. Apabila seorang anak dibiarkan melakukan sesuatu yang kurang baik dan kemudian telah menjadi kebiasaannya, maka akan sukarlah meluruskannya."1

Pernyataan-pernyataan di atas menunjukkan bahwa masa anak-anak merupakan periode yang terpenting (golden age) dalam pendidikan. Maka pendidikan anak hendaknya benar-benar diperhatikan dan dipersiapkan sebaik-baiknya oleh para pendidik seperti orang tua dan guru agar dapat melahirkan generasi bangsa yang siap menjalankan tugas-tugas kehambaan, kekhalifahan dan pewaris Nabi.

Dalam proses menumbuhkembangkan potensi-potensi yang dimiliki anak membutuhkan sebuah metode, pemilihan metode penting untuk dilakukan supaya tujuan pendidikan Islam dapat tercapai. Seorang pendidik diharuskan dapat memilah mana metode yang tepat yang akan digunakan dalam proses pendidikan dan pegajaran. Disinilah seorang pendidik diharuskan untuk menguasai dan menerapkan berbagai macam metode pendidikan. Sehingga anak didik mampu menyerap materi pelajaran dengan baik dan mampu mengamalkan apa yang telah mereka pelajari dalam kehidupan sehari-hari. ${ }^{2}$

Dalam pemilihan sebuah metode hal yang harus diperhatikan adalah materi yang akan diajarkan dan karakter dari seorang anak, karena tidak semua metode dapat diterapkan terhadap semua anak. Selain itu juga harus melihat situasi belajar, materi yang akan diajarkan, tujuan apa yang hendak dicapai dalam materi yang akan diajarkan. Dalam pendidikan Islam sendiri telah banyak ditawarkan berbagai macam metode pendidikan, akan tetapi dari metode-metode tersebut belum mampu mengantarkan anak untuk mengamalkan apa yang telah mereka pelajari dalam kehidupan sehari-hari. Metode yang digunakan masih sebatas untuk memahami dan menghayati materi pelajaran agama Islam. ${ }^{3}$ Meskipun akhirakhir ini berbagai upaya telah dilakukan oleh berbagai lembaga pendidikan dalam

\footnotetext{
${ }^{1}$ Mohd. Athiyah Al-Abrasyi, H Bustami A Gani, and Djohar Bahry LIS, Dasar-Dasar Pokok Pendidikan Islam (Penerbit Bulan Bintang, 1993).

${ }^{2}$ Muh Arifin, "Iklim Pendidikan Islam: Suatu Tinjauan Teoretis \& Praktis Berdasarkan Pendekatan Onterdisipliner," Jakarta: Bina Aksara, 1993.

3 Ahmad Munjin Nasih and Lilik Nur Kholidah, "Metode Dan Teknik Pembelajaran Pendidikan Agama Islam," Bandung: Refika Aditama, 2009, 10-13.
} 
memberikan berbagai pembiasaan yang baik terhadap siswa, seperti mengucapkan salam, berjabat tangn dengan guru, sholat berjamaah, dan lain sebagainya. Hal tersebut dilakukan untuk menumbuhkan akhlak anak, mengingat tujuan utama dari pendidikan agama Islam adalah membentuk akhlakul karimah anak. Upaya-upaya yang dilakukan oleh para pendidik ternyata belum mampu untuk mendorong anak didik dalam tahap pengamalan materi. Dapat dikatakan bahwa pembiasaan di sekolah ini tidak berlanjut dalam kehidupan dalam keluarga dan masyarakat. Sehingga disini dibutuhkan sebuah metode alternatif untuk mewujudkan tujuan pendidikan Islam.

Penelitian ini akan mendeskripsikan tentang strategi pembelajaran materi PAI dengan metode hypnoteaching untuk siswa SD. Hypnosis telah dikenal sejak ribuan tahun yang lalu dalam bentuk yang masih tradisional dalam semua kebudayaan yang ada dunia. Pada abad ke18, Franz A. Mesmer mempopulerkan hypnosis untuk proses pengobatan. Setelah dilakukan berbagai penelitian, hypnosis ditetapkan menjadi salah satu cabang ilmu pengetahuan ilmiah, tanpa unsur mistis atau magis, hal tersebut dilakukan dan ditetapkan setelah proses penelitian yang dilakukan oleh Dr. Erickson M.D, Dave Elman, Charles Tebbets, dan tokoh hypnosis modern lainnya. Sekarang ini, hypnosis bangkit dengan dukungan teknologi dan temuan-temuan ilmiah yang relevan. ${ }^{4}$ Dalam masyarakat kita istilah hypnosis lebih dikenal sebagai hipnotis. Yangmana masyarakat kita menganggap bahwa dalam proses hypnosis atau hipnotis ini terdapat unsur magis dan sering digunakan dalam berbagai penipuan dengan mempengaruhi pikiran bawah sadar seseorang yang dijadikan target.

Hypnosis menjadikan pikiran bawah sadar manusia sebagai penerima sugesti. Dalam setiap aktivitasnya manusia senantiasa menggunakan pikiran sadar (conscious mind) dan pikiran bawah sadarnya (unconscious mind). Pikiran sadar berfungsi sebagai pikiran yang analitis, rasional, kekuatan untuk melakukan sesuatu, faktor kritis, dan memori jangka pendek, yang seringkali disamakan dengan otak kiri. Sedangkan fungus dari pikiran bawah sadar yaitu untuk menyimpan memori jangka panjang, intuisi, kebiasaan, emosi, dan yang seringkali disetarakan dengan otak kanan. Pikiran sadar dan pikiran bawah sadar berisi program-program yang berdampak kepada perilaku dan tindakan. ${ }^{5}$ Dalam hal ini, alam bawah sadar mendominasi pikiran manusia.

Dalam dunia pendidikan, kegiatan hypnosis disebut dengan Hypnoteaching merupakan perpaduan dari dua kata, yaitu "hypno" yang berarti suggesti dan "teaching" yang berarti mengajar. Sehingga dapat diartikan bahwa hypnoteaching adalah adalah menghipnotis atau mensugesti siswa agar menjadi pintar dan melejitkan semua anak menjadi bintang. Hypnoteaching adalah perpaduan pengajaran yang melibatkan pikiran sadar dan pikiran bawah sadar. ${ }^{6}$ Hypnosis adalah penyadaran melalui alam bawah sadar. Dalam hal ini guru adalah hipnoterapis dan siswa sebagai penerima hipnoterapis. Dalam prakteknya, saat materi pelajaran, siswa diminta rileks, tenang dan konsentrasi pada materi yang disampaikan guru.

\footnotetext{
${ }^{4}$ Abdul Khafi Syatra, Misteri Alam Bawah Sadar Manusia (Yogyakarta: DIVA PRESS, 2010).

${ }^{5}$ Syatra.

${ }^{6}$ Syatra.
} 
Penelitian tentang hypnoteaching ini sudah banyak dilakukan, diantaranya penelitian yang dilakukan oleh Sunanih yang berjudul "Metode Hypnoteaching untuk Anak Sekolah Dasar", menyimpulkan bahwa hypnoteaching adalah sebuah metode yang tepat dan sangat baik digunakan untuk anak usia SD. Hynoteaching sangat bagus dalam merangsang konsentrasi pada anak. Dengan diterapkannya metode ini diharapkan terjadi peningkatan dalam proses pembelajaran, sehingga tujuan pendidikan dapat tercapai. ${ }^{7}$

Dengan penulisan artikel ini diharapkan metode hypnosis dapat memberikan solusi dalam penyampaian materi pelajaran sehingga diharaplan siswa lebih mudah dalam menerima materi dan siswa memiliki perubahan pada aspek akhlak sesuai dengan apa yang disampaikan, siswa lebih mudah untuk diajak kerjasama dalam proses pembelajaran, dan lebih memiliki motivasi dalam belajar.

\section{B. METODE PENELITIAN}

\section{Pendekatan dan Jenis Penelitian}

Penelitian ini menggunkan pendekatan kualitatif dimana suatu pendekatan penelitian yang bertujuan untuk mendeskripsikan dan menganalisa kejadian-kejadian di masyarakat sepert, aktivitas sosial, sikap, kepercayaan, persepsi, pemikiran orang secara individu maupun kelompok. ${ }^{8}$ Dalam penelitian ini, penulis mengkaji tentang strategi pembelajaran materi PAI dengan metode hypnosis di SD.

Penelitian tentang strategi pembelajaran materi PAI dengan metode hypnosis di SD ini merupakan kajian kepustakaan atau library research. Penelitian dilakukan dengan menelaah berbagai literature yang relevan dengan penelitian dan menganalisis secara mendalam untuk memecahkan masalah penelitian. ${ }^{9}$ Berbagai literature yang digunakan merupakan sumber ide untuk menggali pemikiran atau gagasan baru, sebagai bahan dasar untuk melakukan deduksi dari pengetahuan yang telah ada, atau sebagai pemecahan masalah yang ada sehingga dapat membangun dan mengembangkan kerangka teori baru. Dalam penelitian ini penulis mengumpulkan data-data berupa materi-materi tentang metode hypnosis.

\section{Sumber Data}

Dalam penelitian ini sumber data yang digunakan berasal dari berbagai literatur kepustakaan yang relevan dengan penelitian. Dalam hal ini penulis akan menyebutkan beberapa sumber data primer dan sekunder.

a. Sumber Data Primer

Sumber primer yaitu merupakan sumber utama yang mana literatur yang ada merupakan sebuah hasil karya ataupun hasil penelitian yang orisinil. ${ }^{10}$ Sumber data primer yang digunakan dalam penelitian adalah karya Novian Triwidia Jaya dengan

\footnotetext{
7 Sunanih Sunanih, "METODE HIPNOTEACHING UNTUK ANAK SEKOLAH DASAR," NATURALISTIC: Jurnal Kajian Penelitian Pendidikan Dan Pembelajaran 3, no. 1 (2018): 247-53.

${ }^{8}$ Nana Syaodih Sukmadinata, Metodologi Penelitian Pendidikan (Bandung: REMAJA ROSDA KARYA, 2009).

9 Sugiyono, "Metode Penelitian Kuantitatif Kualitatif Dan R\&D" (CV. Alfabeta, Bandung, 2011).

${ }^{10}$ Imam Gunawan, "Metode Penelitian Kualitatif," Jakarta: Bumi Aksara 143 (2013).
} 
judul Hypnoteaching Bukan Sekadar Mengajar. Hypnoteaching Bukan Sekadar Mengajar terbitan D-Brain tahun 2010.

b. Sumber Data Sekunder

Sumber Data Sekunder adalah sebagai bahan pendukung dalam penelitian yang mana literature yang ada merupakan hasil pengamatan seorang penulis atau peneliti yang telah dipublikasikan. Dalam hal ini peneliti bukanlah penemu dari sebuah teori. Sumber ini berisi tentang hasil perpaduan dari berbagai pengertian yang berasal dari bahan-bahan sumber utama, baik itu secara teoritis maupun empiris. ${ }^{11}$ Adapun yang menjadi sumber data sekunder yang menjadi pendukung adalah referensi-referensi yang berkaitan dengan hypnosis adalah karya Abdul Khafi Syatra dengan judul Misteri Alam Bawah Sadar Manusia terbitan Diva Press tahun 2010.

\section{Teknik Pengumpulan Data}

Teknik pengumpulan data yang digunakan untuk memperoleh data-data tentang metode hypnosis adalah dengan mengumpulkan data-data literer yang berkaitan dengan tema penelitian yaitu dengan menggali bahan-bahan pustaka yang koheren. ${ }^{12}$ Maka pengumpulan data-data penelitian disini yaitu melalui pengumpulan buku-buku dan artikel yang membahas tentang pengertian dan langkah-langkah dalam melakukan hypnosis dan ataupun hypnoteaching.

\section{Analisis Data}

Terkumpulnya data tesebut kemdian dioleh menngunakan metode analisis. Metode analisis ialah cara yang digunakan untuk mendapatkan ilmu pengetahuan ilmiah dengan melakukan pemerincian terhadap obyek ilmiah dengan cara memilah antara pengertian yang satu dengan yang lainnya. ${ }^{13}$ Atau analisis isi adalah suatu teknik yang digunakan dalam sebuah penelitian untuk membuat kesimpulan-kesimpulan berdasarkan buktibukti pendukung yang dapat ditiru dan salin data dengan memperhatikan tema

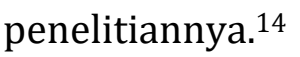

\section{HASIL DAN PEMBAHASAN}

Anak merupakan aset bangsa yang sangat berharga, untuk itu mengapa pendidikan anak sangat diperhatikan oleh para pakar pendidikan. Menurut mereka, usia anak-anak adalah usia yang paling tepat untuk menumbuhkembangkan segala potensi yang dimiliki, sehingga perkembangan anak dapat terjadi secara optimal. Karena apa yang mereka pelajari dan mereka dapatkan saat ini akan berpengaruh besar terhadap perkembangan mereka masa selanjutnya. Seperti apa yang telah dikatakan oleh Ibn al-Jauzi misalnya, dalam al-Tib alRuhani yang mana telah dikutip oleh Moh. Athiyah al-Abrasyi menyatakan bahwa, "Pembentukan yang utama ialah di waktu kecil. Apabila seorang anak dibiarkan melakukan

\footnotetext{
${ }^{11}$ Gunawan.

12 Arikunto Suharsimi, “Prosedur Penelitian Suatu Pendekatan Praktik,” Jakarta: Rineka Cipta, 2006, 120 -23.

${ }^{13}$ Burhan Bungin, “Metodologi Penelitian," Jakarta: Kencana, 2017.

${ }^{14}$ Klaus Krippendorff, “Analisis Isi Pengantar Teori Dalam Metodologi, Terjemahan,” FaridWajidi, Jakarta: PT. Raja Grafindo Persada, 1993.
} 
sesuatu yang kurang baik dan kemudian telah menjadi kebiasaannya, maka akan sukarlah meluruskannya."15

Pernyataan-pernyataan di atas menunjukkan bahwa masa anak-anak merupakan periode yang terpenting (golden age) dalam pendidikan. Maka pendidikan anak hendaknya benar-benar diperhatikan dan dipersiapkan sebaik-baiknya oleh para pendidik seperti orang tua dan guru agar dapat melahirkan generasi bangsa yang siap menjalankan tugas-tugas kehambaan, kekhalifahan dan pewaris Nabi. Dalam penelitian ini, anak yang dimaksud adalah anak usia 6-12 tahun, yang mana pada usia ini jenjang pendidikan mereka adalah sekolah dasar. Pada masa ini adalah dimana masa pengetahuan anak-anak akan bertambah semakin pesat beriringan dengan bertambahnya usia mereka, keterampilan yang dikuasainyapun semakin bertambah dan beragam. Minat atau keinginan anak terhadap sesuatu pada periode ini terfokus pada segala sesuatu yang bersifat dinamis bergerak. Implikasi yang ada adalah anak cenderung untuk melakukan beragam aktivitas yang mana hal tersebut akan berguna pada proses perkembangan selanjutnya. ${ }^{16}$

Dalam hal ini maka pemilihan metode yang tepat dapat mengoptimalkan hasil pendidikan. Beberapa tahun telah dikenal sebuah metode pendidikan yang sangat menarik yang disebut Hypnoteaching. Kata hypnoteaching berasal dari perpaduan dua kata, yaitu hypno dan teaching. Hypno yang berarti suggesti dan teaching yang berarti mengajar. Dari perpaduan kata tersebut dapat diartikan bahwa hypnoteaching adalah adalah menghipnotis atau memberi sugesti kepada siswa agar menjadi beprestasi dan untuk mendorong semua anak menjadi bintang. Hypnoteaching merupakan perpaduan pengajaran yang membutuhkan pikiran sadar dan pikiran bawah sadar dalam proses pembelajaran. ${ }^{17}$ Di dalam kegiatan pembelajaran, hypnosis dapat digunakan sebagai alat untuk memotivasi siswa, meningkatkan keorganisasian, kedisplinan, kepercayaan diri, dan kemampuan berkonsentrasi. Ketrampilanketrampilan tersebut dapat dipastikan meningkat melalui terapi hypnosis. ${ }^{18}$

Awal mula kata hypnosis sendiri berasal dari Yunani yaitu hypnos yang merupakan dewa tidur Yunani. James Braid, seorang dokter ternama Inggris (1795-1860) adalah orang yang pertamakali mengenalkan tentang metode hypnosis sebagai pengobatan. Sebelumnya, hypnosis dikenal dengan sebutan mesmerism ${ }^{19}$ yang dipopulerkan oleh Franz A. Mesmer. Definisi hypnosis yang dibuat oleh U.S. Departement of Education, Human Service Division adalah penembusan faktor kritis pikiran sadar yang diikuti dengan diterimanya suatu pemikiran atau sugesti. ${ }^{20}$

Ferdiansyah Setiadi Setiawan, ketua IBH (Indonesian Board of Hypnoterapy) berpendapat bahwa, dengan seseorang yang mengistirahatkan pikiran sadarnya (Consious Mind) melalui hypnosis, dapat diberikan ingatan yang kuat, saran, atau sugesti yang dapat

\footnotetext{
${ }^{15}$ Al-Abrasyi, Gani, and LIS, Dasar-Dasar Pokok Pendidikan Islam.

${ }^{16}$ Herka Maya Jatmika, "Pemanfaatan Media Visual Dalam Menunjang Pembelajaran Pendidikan Jasmani Di Sekolah Dasar," Jurnal Pendidikan Jasmani Indonesia 3, no. 1 (2005).

${ }^{17}$ Novian Triwidia Jaya, “Hypno-Teaching (Bukan Sekedar Mengajar),” Bekasi: D-Brain, 2010.

${ }^{18}$ Syatra, Misteri Alam Bawah Sadar Manusia.

${ }^{19}$ Jaya, "Hypno-Teaching (Bukan Sekedar Mengajar)."

20 Jaya.
} 
memprogram ulang pikiran bawah sadarnya untuk berbagai tujuan positif dan bermanfaat. ${ }^{21}$ Hypnoterapi merupakan sebuah metode yang tepat digunakan untuk menjangkau pikiran bawah sadar, melakukan edukasi, dan menyembuhkan pikiran yang sakit dengan mudah, cepat, efektif, dan efisien. ${ }^{22}$ Selain itu, pada tahun 1955, berdasarkan penelitian yang dilakukan oleh British Medical Association dinyatakan bahwa hypnosis layak digunakan untuk mengobati hysteria dan dapat digunakan sebagai anastesi. Penelitian lainnya tentang hypnosis ini dilakukan oleh Proffessional Affairs Board of the British Psychology Society pada tahun 2001, hasil penelitian tersebut adalah hypnosis dapat digunakan untuk mengurangi rasa cemas, stress, dan masalah-masalah yang berkaitan dengan psikologis lainnya. Dalam perkembangan selanjutnya, hypnosis dapat digunakan untuk membantu mengembangkan performa diri dan dapat membantu dalam proses pembelajaran. ${ }^{23}$

Dalam jurnal newscientist.com, seorang psikolog yang bernama John Gruzelier dari Imperial College di London melakukan riset dengan menggunakan Fmri, sebuah alat untuk mengetahui aktivitas otak, menemukan bahwa seseorang yang berada dalam keadaan terhipnosis, aktivitas otaknya meningkat. Khususnya di bagian otak yang berpengaruh terhadap proses berpikir tingkat tinggi dan perilaku. Dia menyebutkan bahwa manusia saat terhipnosis mampu melakukan hal-hal yang dia sendiri tidak berani memimpikannya. Sehingga hypnosis sangat berdampak dalam memotivasi dan meningkatkan kinerja.

Sandy mc Gregor, dalam bukunya Peace of Mind, menyatakan bahwa pengaruh pikiran bawah sadar sangatlah kuat dan benar-benar dapat menguasai hampir seluruh pemikiran seseorang dengan hitungan prosentase sebanyak 88\%. Sedangkan pikiran sadar hanya menyisakan pengaruh sekitar $12 \%$ saja dari total penguasaan. Dengan demikian, kita dapat meningkatkan kecerdasan dalam diri kita dengan cara memaksimalkan kemampuan pikiran bawah sadar yang kita miliki. ${ }^{24}$

Alam bawah sadar kita adalah sebuah database raksasa yang di dalamnya memiliki sebuah sistem operasi yang sangat canggih. Akan tetapi, bangunan pikiran bawah sadar tidaklah selalu kokoh, bangunan bawah sadar dapat ambruk sewaktu-waktu ketika bahaya mengancam, sama halnya seperti sebuah sistem komputer yang sangat rentan terhadap serangan virus yang dapat mengakibatkan rusaknya alam bawah sadar, seperti perasaan takut, panik, emosi yang berlebihan, trauma, dan perasaan negatif lainnya. Namun kerusakan tersebut dapat kita selamatkan karena alam bawah sadar bukanlah sesuatu yang paten, kita dapat membentuk alam bawah sadar kita melalui tahapan-tahapan yang telah ditentukan. Tahapan-tahapan yang dilakukan untuk menyelamatkan pikiran bawah sadar kita dari bahaya yang mengancam tersebut adalah dengan selalu memiliki sikap positif thinking dan rasa percaya diri yang tinggi. ${ }^{25}$

Fungsi dari pikiran bawah sadar yaitu untuk memproses keyakinan, intuisi, kreativitas, kepribadian, persepsi, memori permanen, perasaan dan kebiasaan. Hal tersebut sangat

\footnotetext{
${ }^{21}$ Syatra, Misteri Alam Bawah Sadar Manusia.

22 Syatra.

${ }^{23}$ Jaya, "Hypno-Teaching (Bukan Sekedar Mengajar)."

${ }^{24}$ Jaya.

${ }^{25}$ Syatra, Misteri Alam Bawah Sadar Manusia.
} 
berbeda dengan pikiran sadar yang memiliki empat fungsi utama, yaitu mengenali informasi yang masuk dari panca indra, membandingkan dengan memori kita, menganalisis, dan kemudian memutuskan respon spesifik terhadap informasi tersebut. ${ }^{26}$

Setelah diteliti lebih lanjut pikiran bawah sadar kita ternyata jauh lebih cepat, bijaksana, dan cerdas dibandingkan dengan pikiran sadar. Pikiran bawah sadar kita mampu menangani 2.300.000 bit informasi dalam satu kurun waktu. Sedangkan pikiran sadar kita hanya mampu menangani 7-9 bit informasi dalam satu kurun waktu. Dari data tersebut dapat disimpulkan bahwa apa yang tidak bisa ditangkap oleh pikiran sadar dapat dipahami dan dimengerti oleh pikiran bawah sadar. ${ }^{27}$ Pikiran bawah sadar pada dasarnya selalu sadar dan waspada. Pikiran bawah sadar selalu responsive terhadap setiap kejadian. Lalu kenapa disebut tidak sadar? Hal tersebut dikarenakan manusia pada umumnya tidak mengetahui keberadaan pikiran bawah sadarnya. Pada saat ke 5 indera sudah tidak aktif, bahkan ketika pikiran sadar sedang tidak aktif, pikiran sadar justru mengetahui atau menyadari segala sesuatu yang ada dipikiran sadar. $^{28}$

Dengan menggunakan pikiran bawah sadar, kemampuan berpikir kita akan meningkat 10.000 kali lebih cepat daripada pikiran sadar. Dibawah ini adalah tahapan gelombang otak:

1. Beta

Kondisi ini merupakan kondisi dimana seseorang dalam tahap sangat sadar, dengan gelombang otak antara 12-25 putaran per detik. Sebuah kondisi dimana kita sangat kritis, analitis, dan waspada, dan tahap ini adalah tahap dimana pikiran sadar mendominasi $100 \%$ dalam proses berpikir.

2. Alpha

Kondisi alpha dapat dikatakan saat seseorang sedang pada tahap relaks, dengan gelombang otak antara 7-12 putaran per detik. Pada kondisi ini rasa kritis, analitis, dan waspada seseorang mulai berkurang. Ketika kita pada kondisi alpha, pikiran kita mulai terbuka terhadap sugesti. Pada tahap ini, peran pikiran sadar hanya mendominasi sekitar 25\% dalam melakukan pemikiran. Kondisi seperti ini biasanya dimiliki pada saat merasa gembira, senang, gembira, berimajinasi, santai, dan menjelang tidur.

3. Theta+

Kondisi theta adalah kondisi kita ketika merasa sangat relaks antara sadar dan tidur lelap dengan gelombang otak antara 4-7 putaran per detik. Pada kondisi ini kita sangat terbuka dengan masukan, pada kondisi ini pikiran sadar sudah tidak berpengaruh. Akan tetapi pikiran bawah sadar tetap aktif dan ke 5 panca indera pun masih aktif sehingga masih dapat menerima sugesti. Cara kerja pikiran bawah sadar adalah tidak mampu membedakan mana yang benar dan salah, dia hanya bekerja berdasarkan perintah. Pada gelombang ini semua program yang telah ada di pikiran bawah sadar dapat dimodifikasi. Sehingga pikiran seseorang dapat dipengaruhi dengan sugesti-sugesti dari luar. Pada tahap inilah hypnosis terjadi.

\footnotetext{
${ }^{26}$ Syatra.

27 Syatra.

${ }^{28}$ Syatra.
} 
4. Delta

Kondisi ini adalah sebuah kondisi dimana kita tidur lelap dengan gelombang 0,5-4 putaran per detik. Pada kondisi pikiran bawah sadar aktif hanya tidak bisa menerima masukan.

Di bawah ini tabel yang menggambarkan tahapan gelombang otak: ${ }^{29}$

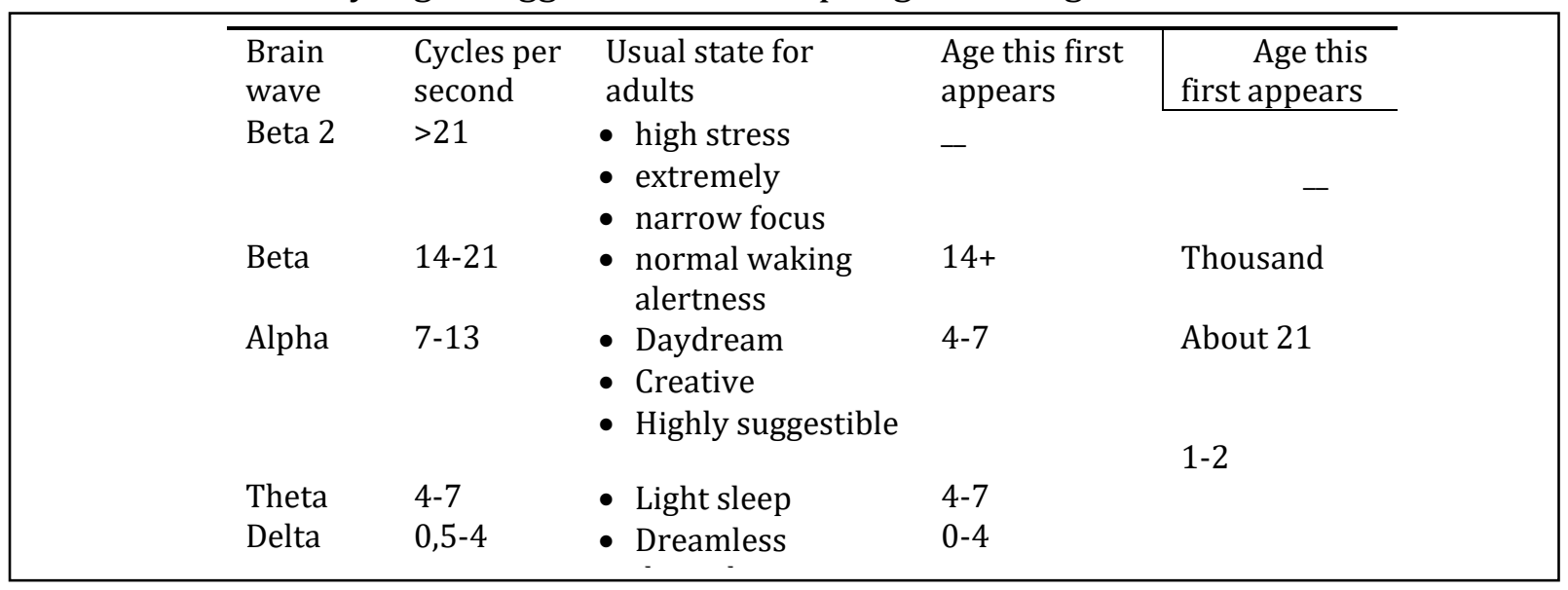

Dari keterangan di atas dapat ditarik kesimpulan bahwa semakin rendah gelombang otak seseorang, maka semakin mudah kita dalam mengaktifkan pikiran bawah sadar kita, karena pada saat terjadi itu pikiran sadar kita berkurang pengaruhnya. Untuk seseorang yang memiliki gelombang otak dengan kategori beta, memerlukan usaha yang lebih lama untuk mempelajari sesuatu karena pikiran sadar yang begitu analitis dan kritis masih sangat aktif. Ada beberapa teknik agar komunikasi dapat berjalan langsung menuju ke pikiran bawah sadar pada tahap kondisi beta, yaitu:

1. Memberikan pengulangan informasi. Disini kita menyampaikan informasi secara berulangulang kepada si penerima informasi. Misalnya: menyampaikan materi pelajaran dengan mengatakan sebanyak 3x secara berurutan.

2. Dengan memiliki ikatan emosional. Informasi dteruskan masuk ke dalam alam bawah sadar jika ada ikatan emosional, yaitu dengan memberikan rasa bahagia, sedih, dan lainlain.

3. Menggunakan bahasa pikiran bawah sadar. Bahasa yang dimaksud adalah bahasa yang selalu diterima dan tidak dapat ditolak oleh pikiran sadar. Bahasa ini dapat berbentuk kalimat juga bahasa tubuh.

4. Dengan menggunakan seseorang yang memiliki kharisma dan wibawa. Seorang tokoh yang disukai anak-anak akan memberikan pengaruh yang sangat besar.

5. Melalui hypnosis. Seseorang dibawa ke level kesadaran tertentu kemudian diberikan sugesti atau masukan-masukan yang bersifat positif. Sugesti itulah yang menjadi informasi yang kemudian dimasukkan ke pikiran bawah sadar seseorang.

Langkah-langkah tersebut akan digabungkan dalam proses hypnoteaching. Sehingga anak-anak akan dibawa dari kondisi beta bisa ke alpha ataupun theta sehingga proses belajar

29 Jaya, "Hypno-Teaching (Bukan Sekedar Mengajar)." 
mengajar menjadi lebih efektif dan efisien. ${ }^{30}$ Dalam dunia pendidikan, proses hypnosis tidak sampai pada tahap dimana kesadaran anak tercabut. Siswa tetap sadar, namun sejatinya telah terhypnosis oleh sugesti guru, baik kata-kata maupun sikap guru. Sehingga siswa mematuhi apa yang diucapkan oleh guru tanpa bantahan sedikitpun. Hypnoteaching yang kita kenal tidak sama dengan hypnosis yang membuat orang tidur yang tanpa sadar mau diperintah apa saja oleh penghypnotisnya. ${ }^{31}$

Berdasarkan uraian tersebut di atas dapat kita ambil kesimpulan bahwa terdapat tiga hal penting yang saling berkaitan antara satu dengan yang lain, yaitu tujuan pendidikan Islam; materi pendidikan Islam dan metode pendidikan Islam. Dalam hal ini lebih ditekankan akan pentingnya pengkajian secara mendalam tentang metode pendidikan Islam. Hal tersebut dilakukan supaya pendidikan Islam dapat diketahui, dihayati, dipahami, dimengerti, dan diamalkan oleh peserta didik dalam kehidupan sehari hari, maka metode yang tepat diperlukan dalam proses pendidikan Islam. Melalui metode hypnosis ini anak-anak memiliki perubahan pada aspek akhlak sesuai dengan apa yang disampaikan, anak-anak lebih mudah untuk diajak kerjasama dalam proses pembelajaran, dan anak-anak lebih memiliki motivasi dalam belajar dan mengamalkan dalam kehidupan sehari-hari.

\section{E. PENUTUP}

\section{Simpulan}

Berdasarkan hasil telaah pustaka yang telah diuraikan diatas, dapat disimpulkan bahwa pembelajaran PAI dengan menggunakan metode hypnosis siswa dapat memahami dan menghayati materi PAI dengan baik. Selain itu, perubahan akhlak yang baik juga dapat diacapai melalui sugesti-sugesti positif, dan motivasi yang diberikan oleh guru sebagai hypnoterapi. Hypnoteaching juga dapat digunakan untuk memotivasi siswa dalam mengamalkan ajaran-ajaran Islam dalam kehidupan sehari-hari. Mengingat bahwa sugestisugesti positif dan sikap yang diberikan oleh guru diterima tanpa bantahan oleh siswa.

\section{Saran}

Berdasarkan hasil penelitian bahwa hypnoteaching merupakan salah satu metode yang efektif dalam meningkatkan pembelajaran PAI di SD, mengingat bahwa dalam pendidikan Islam sangat memperhatikan tumbuh kembang anak di awal kehidupan.

\section{F. DAFTAR PUSTAKA}

Al-Abrasyi, Mohd. Athiyah, H Bustami A Gani, and Djohar Bahry LIS. Dasar-Dasar Pokok Pendidikan Islam. Penerbit Bulan Bintang, 1993.

Arifin, Muh. "Iklim Pendidikan Islam: Suatu Tinjauan Teoretis \& Praktis Berdasarkan Pendekatan Onterdisipliner." Jakarta: Bina Aksara, 1993.

Bungin, Burhan. “Metodologi Penelitian.” Jakarta: Kencana, 2017.

Gunawan, Imam. “Metode Penelitian Kualitatif." Jakarta: Bumi Aksara 143 (2013). 
Jatmika, Herka Maya. "Pemanfaatan Media Visual Dalam Menunjang Pembelajaran Pendidikan Jasmani Di Sekolah Dasar." Jurnal Pendidikan Jasmani Indonesia 3, no. 1 (2005).

Jaya, Novian Triwidia. "Hypno-Teaching (Bukan Sekedar Mengajar).” Bekasi: D-Brain, 2010.

Krippendorff, Klaus. "Analisis Isi Pengantar Teori Dalam Metodologi, Terjemahan." FaridWajidi, Jakarta: PT. Raja Grafindo Persada, 1993.

Nana Syaodih Sukmadinata. Metodologi Penelitian Pendidikan. Bandung: REMAJA ROSDA KARYA, 2009.

Nasih, Ahmad Munjin, and Lilik Nur Kholidah. "Metode Dan Teknik Pembelajaran Pendidikan Agama Islam." Bandung: Refika Aditama, 2009, 10-13.

Sugiyono. "Metode Penelitian Kuantitatif Kualitatif Dan R\&D." CV. Alfabeta, Bandung, 2011.

Suharsimi, Arikunto. "Prosedur Penelitian Suatu Pendekatan Praktik." Jakarta: Rineka Cipta, 2006, 120-23.

Sunanih, Sunanih. "metode hipnoteaching untuk anak sekolah dasar." Naturalistic: Jurnal Kajian Penelitian Pendidikan Dan Pembelajaran 3, no. 1 (2018): 247-53.

Syatra, Abdul Khafi. Misteri Alam Bawah Sadar Manusia. Yogyakarta: DIVA PRESS, 2010. 